\title{
PROCESS OF DEINSTITUTIONALIZATION OF CHILDREN AT RISK IN BULGARIA
}

\author{
Venelin Terziev \\ Academician of the Russian Academy of Natural History, Moscow, Russia, Prof. D.Sc. (Ec.), D.Sc. \\ (National Security), D.Sc. (Social Activities), Ph.D., National Military University, Veliko Tarnovo, \\ Bulgaria; University of Rousse, Rousse, Bulgaria, terziev@skmat.com
}

\begin{abstract}
In recent years in Bulgaria the type of institutional care for children at risk is changing giving priority to family and close to family environment. The will to implement this process of all involved responsible agencies, institutions and non-governmental organizations has found expression in a number of regulations, strategic and program documents, as well as innovative and successful practices. Economic, political and social changes that accompany the transition has led to new problems and exacerbated existing problems. Current study makes analyses of the national strategy for deinstitutionalization of children and concludes on important recommendations concerning national policy development. The policy should be based on the respect of child rights, norms, standards and principles of universality, indivisibility and nondiscrimination, while characterized by high sensitivity, flexibility and preparedness to meet the challenges. It is important and necessary to develop a policy that will not only offer appropriate care for children at risk in the short term, but will prevent similar problems in the future.
\end{abstract}

Keywords: child, deinstitutionalization; social integration.

\section{INTRODUCTION}

Deinstitutionalization is the process of replacing institutional care for children with care in a family or family like environment in the community, not limited to the children leaving institutions. This is the process of preventing the placement of children in institutions, creating new opportunities for children and families to receive support in the community. It takes place on many levels (2010a): working with families and professionals from social and close to it fields on prevention of abandonment and institutionalization of children with a view to the limiting and gradually cease of placing children in institutions and to support the reintegration of children in their native families; reform and work in the social welfare system for the implementation of programs for social support and protection to support the native and the extended family for the prevention of abandonment and encouragement of growing children in a family environment; provision of alternative forms of services and care in order to create opportunities for children to leave institutions or prevent their accommodation; promotion and development of adoption fostering care with a focus on development of services for children 0-3 years; engaging the public in the support to children leaving institutions and their social inclusion; putting children and families at the center of the work of all working with children. 
The main principles as accepted by the National strategy "Vision for deinstitutionalization of children in Bulgaria" are the following: actions to protect the interests of the child according to the UN Convention on the Rights of the Child is the guiding principle that the interests of the child should be placed above the interests of all others, including parents, potential adoptive parents, foster parents or staff of the institution; the family is the best environment for child development - all working in the field of de-institutionalization should have a common understanding about the negative impact that institutional care has on children and how important is child to grow in a family environment; social inclusion of children is paramount - it must be achieved by providing opportunities for all children to participate in all aspects of community life, incl. attending local kindergartens and schools and use local health, transport and other public services.

Some of the key factors that influence the institutionalization are: insufficient number of services for children and families that meet complex needs and uneven distribution throughout the country; lack of financial resources, which often resulted in the exclusion of families and placement of children in institutions; lack of developed system of alternatives to institutional care community-based; prevailing medical model to child's disabilities, according which the institution offer the best care for children; lack of inclusive social and architectural environment; changed patterns of family behavior that lead to an increase in illegitimate births and parents who provide care for children by their own.

The process of deinstitutionalization of children in the Republic of Bulgaria enters its most important phase in 2014. It is the most important stage - the actual change for children from the specialized agencies and placing them in new services, supported by the implementation of projects that are working to implement the National strategy for deinstitutionalization of children in the Republic of Bulgaria (2010a) and the action plan to it (Action plan for the implementation of the National strategy "Vision for deinstitutionalization of children in Bulgaria"). They are funded by European structural funds through operational programs and carried out by the State agency for protection of children, Social Assistance Agency at the Ministry of labor and social policy and Ministry of health. Despite investment, life of children in residential care is not getting better, neither quality services get better. Institutional organization of life cannot meet the basic needs of children, and has a negative impact on their development and behavior. This, in turn, leads to further economic and social cost to society.

\section{PECULIARITIES OF THE PROCESS OF DEINSTITUTIONALIZATION IN BULGARIA: PROBLEMS AND PERSPECTIVES}

Institutions for children are part of the legacy left by the totalitarian state, which established the policy based on the idea that the state is able to better care for children than their families. This policy continued for more than 40 years and left lasting traces on public attitudes and mentality of people in the country. Twenty years after the political changes, the institutionalization of child care in Bulgaria continues to be an unresolved issue that cannot be explained only with the totalitarian past. The lack of clear political will to close the homes lead to their "reform" and "restructuring", which are often has been perceived as repairs of the buildings and did not lead to a significant change in the way of care and children's lives.

Not all establishments that provide care and shelter for children are defined as an institution. As institutions are identified those imposing strict life that do not provide necessary attention and individual care, vital for the development of a child lacking personal concern of the people with whom he/she is in contact. Often children stay indefinitely. Usually they are unable to maintain relations with their biological parents and there are no attempts to support the families with the aim of reintegration of the children if it is in their best interest (Deinstitutionalization and myths associated with it. Progress Program 2007-2013. (Euro child, Hope and Homes for Children - Bulgaria).

Collected data (2010a) in December, 2009 show the existence of 137 boarding institutions (Table 1). Annual allowance per child amounts to over 3000 euro for different types of institutions. Total annual allowance per institution provided by budgetary grants amounts to over 4 million euro. In addition to the budgetary grant pointed above donations in cash and kind only for specialized institutions in 2008 amounted to near 3 million euro for 2008. The trend towards reducing the number of children placed in institutions, started even before the adoption of the national strategy, but in the period 2010-2014 it has accelerated and it is fair to acknowledge that in a greater part this was due to work on the projects of the national plan for deinstitutionalization (Position of the Coalition "Childhood 2025" on the process of deinstitutionalization in Bulgaria.). 
Table 1. Boarding institutions where children are permanently separated from the family environment (excluding educational boarding schools and social and pedagogical boarding schools).

\begin{tabular}{|c|c|c|c|c|c|}
\hline $\begin{array}{c}\text { Type of an } \\
\text { institution }\end{array}$ & Number & $\begin{array}{c}\text { Number of } \\
\text { accommodated } \\
\text { children }\end{array}$ & $\begin{array}{c}\text { Annual } \\
\text { allowance per } \\
\text { child in the } \\
\text { different types } \\
\text { of institutions } \\
\text { Standard per } \\
\text { child (in euro) }\end{array}$ & $\begin{array}{c}\text { Total annual } \\
\text { allowance for } \\
\text { different types } \\
\text { of institutions } \\
\text { (2009) Annual } \\
\text { allowance (in } \\
\text { euro) }\end{array}$ & $\begin{array}{c}\text { Total amounts } \\
\text { of donations } \\
\text { (2008) } \\
\text { Amount of } \\
\text { donations (in } \\
\text { euro) }\end{array}$ \\
\hline $\begin{array}{c}\text { Homes for } \\
\text { medical and } \\
\text { social care for } \\
\text { children aged } \\
\text { 0-3 years }\end{array}$ & 32 & 2421 & 3366.85 & 14701868.77 & 875131.79 \\
\hline $\begin{array}{c}\text { Homes for } \\
\text { children } \\
\text { deprived of } \\
\text { parental care } \\
\text { aged 3-18 } \\
\text { years }\end{array}$ & 80 & 3770 & 3430.77 & 18987846.59 & 1288849.24 \\
\hline $\begin{array}{c}\text { Homes for } \\
\text { mentally } \\
\text { retarded } \\
\text { children and } \\
\text { homes for } \\
\text { children with } \\
\text { physical } \\
\text { disabilities }\end{array}$ & $24+1$ & 1386 & 3906.27 & 6375042.82 & 772586.06 \\
\hline $\begin{array}{c}\text { Total number / } \\
\text { Total amount }\end{array}$ & 137 & 7577 & & & \\
\hline
\end{tabular}

\section{GOALS AND APPROACHES IN THE RECENT REFORMS IN THE SYSTEM OF DEINSTITUTIONALIZATION OF CHILDREN IN BULGARIA}

The main goal in the undertaken reform is to guarantee children's right to a family environment and access to quality care and services according to their individual needs.Among the specific goals the following should be mentioned (2010a): legislative regulation, funding and staffing of a wide range of services for children and families in the community on the basis of the best practices and attracting innovative approaches;increasing the capacity in the system of child protection by clearly defined and efficient allocation of powers and responsibilities of child protection, service providers and the provision of adequate professional capacity for the effective operation of the system;closure of 137 institutions for children within 15 years from the adoption of the national strategy;prevention of the placement and growing children from 0 to 3 years in residential care of any type after the reform.Long-term goals in the reform of the system are focused on: creation of services for prevention of the placement of children under 3 years outside of their families and the development of alternative family care for children who are separated from their families; and replacement of homes for children with new integrated services in the field of health and social welfare in community to support families with young children and special attention is directed to children with disabilities. Short-term goals include development and implementation of projects aimed at providing integrated services in the field of health and social welfare.

The approaches in the process of the deinstitutionalization could be summarized as follows:for each child there should be implemented needs' assessments that include an evaluation of parental capacity and the opportunities the child to be grownup in his/her family;no child should be taken out of an institution without a plan of action and care co-developed with the people which are taking careof him/her and will in the future, and featuring his birth family when possible;maintaining contact and emotional connection between the 
biological family and the child, whenever possible, should be a key element of providing constant care for each child, whether or not there is an opportunity for future reintegration;for all children from institutions intended for closure accommodation should be provided in a family or family-like environment, no child should be omitted;institutions are not closed by moving children from one institution to another;advantage to accommodation in a family environment is provided - in service demand, alternatives to stay in an institution, first all efforts should be made to reintegrate the child into his/her family home when it is appropriate and it does not endanger the child's life. Where this is not possible, opportunities to be sought for long-term solutions in the best interest of the child initially searching for accommodation in a family of friends or relatives, then in foster or adoptive parents;children are placed in residential care services for small children only when it is not possible family accommodation, and the demand for family form of care in the system of protection does not stop with the placement;search for a permanent solution for the child is a key part of the action planand its monitoring (Action plan for the implementation of the National strategy "Vision for deinstitutionalization of children in Bulgaria") to minimize the transfer from one form of care to another;children should be included as much as possible in making decisions about the form of care that will be selected;siblings must be kept together, unless it is not appropriate and possible;after taking out children of the institutions, their capacity must be reduced to the final closure;with priority will be closed institutions for children with disabilities in parallel with homes for medical and social care of 0-3 years as stay of children in institutions of this kind and at this age is the most detrimental to their development;active involvement of staff of the institutions in the process of deinstitutionalization, development and implementation of programs for retraining and directing staff to alternative social services in order to use the existing capacity and human resources.

\section{EXPERIENCE IN PROJECT IMPLEMENTATION AND RECOMMENDATIONS}

The process of deinstitutionalization so far have shown a number of risks and challenges, some of which are related to specific projects of the national plan, others refer to the process as a whole (Position of the Coalition "Childhood 2025" on the process of deinstitutionalization in Bulgaria). The example of the project "Childhood for all" shows that troubling practices about moving children from institutions to new residential services are displayed. Children are moved without updating their assessments or without preparation. That's why sometimes this led to the return of "serious cases" from small group homes to institutions again. There are serious concerns that the relocation is carried out not by the best interests of children, but with view on the need to be filled in the places in the new services. The methodology for funding services only on the basis of the number of children placed without a separate standard maintenance services creates dependence and desires to place children in order to provide the allowance. The other observed serious problems are with the transfer of information from "the old" to "the new" services and the uncertainty about which children where are housed, as well as lack of any information on the lives of children in new services and what happens after moving. Furthermore, there is a high level of staff turnover and lack of motivationdue to low pay and lack of training and supervision as well as low capacity to dealwith challenging behavior.

The system of child protection is the key to the process of deinstitutionalization. For this reason the national plan were set projects and initiatives through which its capacity to be built. Unfortunately, departments "Child Protection" continue to operate under congestion and shortage of all types of resources. There is a huge turnover among social workers, making it difficult workflows in the system and work with families at risk. A major problem is the lack of standards and training of social workers to work on individual cases and the lack of an adequate support in the form of training, supervision, equipment and more.

The analyses of the practices in the period 2010-2014 has led to the recommendation for a "new"national plan for deinstitutionalization of children including the following goals (Position of the Coalition "Childhood 2025" on the process of deinstitutionalization in Bulgaria): preventing separation of children from their parents, including prevention of abuse and neglect,increasing the effectiveness of the protection system;deinstitutionalization of child care and provision of alternative care.Some other statements (2012a) focus on the improper planning of projects' goals and expected results. Considering the project "I have a family too" it is stated that the role of nongovernmental organizations is not clear as a provider of social services and they were excluded from the application opportunities. Furthermore, it is underlined that the approach local administrations to act as social services providers suffers the lack of experience and resources. The recommendations are connected to the need of encouragement of the collaboration between local authorities and nongovernmental organizations. There are a number of critics to other implemented projects too (2012a) but the accent that should be pointed is the following:development of a mechanism to monitor the quality of social services for children and family that is result-oriented and allows for comparison of performance of different providers;licensing of all providers and certification of providers according to the quality of their services;elaboration of standards for social work with children, as well as standards regarding the acquisition of the profession of social worker and further improvement.The recommendations could be 
summarized as follows (2013a): essence and attitudes towards deinstitutionalization, management and implementation of the process, resources and expertise, and community services development (Terziev, Georgiev, 2018a-d; Terziev, Banabakova, Georgiev, 2018e-o; Dimitrova, Georgiev, 2017a-b; Terziev, Banabakova, Arabska, 2018p; Terziev, Arabska, Banabakova, Kovalyov, 2018q; Terziev, Arabska, Banabakova, Ignatova, Kovalyov, 2018r; Terziev, Arabska, Banabakova, 2018s; Terziev, 2016a; Terziev, 2017c; Terziev, Radev, Arabska, Dimitrovski, 2017d; Terziev, 2017e).

\section{CONCLUSION}

The use of an effective policy for the deinstitutionalization requires a change in philosophy about caring for children with a focus on: risk prevention, early intervention, family support and providing a family or close to family environment. Achievement of these goals requires an integrated policy carefully targeted to children and their families, and changes in following sectoral policies: adoption of a broad concept for the welfare of all children and to guarantee their full rights; services to support parents to fulfill their responsibilities towards their children, and not to the state to take on these responsibilities, and to improve the quality and effectiveness of alternative forms of care and services; a modern approach to the care of health, which supports women before, during and after the birth of their children and do not allow sick children and children with special needs to be separated from their parents for long periods of time; an educational system, which have a volume and resources to support the various needs of all children. a child protection system, which is clearly separated from the social assistance system; a favorable and suitable for the child justice system, where every child who appears in court - whether as a victim of a crime or accused of involvement in crime should be considered in the first instance as a child; introduction of a new approach to funding children's services in which resources are directed to the service to meet specific needs of children and their families and efficiency, rather than to the buildings where they are available.

\section{REFERENCE LIST}

National strategy "Vision for deinstitutionalization of children in Bulgaria", (2010a). Sofia, 2010.

Action plan for the implementation of the National strategy "Vision for deinstitutionalization of children in Bulgaria"

Deinstitutionalization and myths associated with it. Progress Program 2007-2013. Eurochild, Hope and Homes for Children - Bulgaria.

Position of the Coalition "Childhood 2025" on the process of deinstitutionalization in Bulgaria.

Problem areas in policy and practices in deinstitutionalization and development of social services for children and families in Bulgaria. (2012a), National Children Network. April, 2012.

Study deinstitutionalization: case of Bulgaria. Oak Foundation - Switzerland, (2013a). New Bulgarian University. Sofia, 2013.

Terziev, V., Georgiev, M. (2018a). A strategic framework for the development of social entrepreneurship in Bulgaria. // Knowledge - International Journal, August 2018, Institute of Knowledge Management, Skopje, Macedonia, 25, 2018, N1, pp. 23-34, ISSN 1857-923X (for e-version), ISSN 2545 - 4439 (for printed version).

Terziev, V., Georgiev, M. (2018b). Support for the development of social entrepreneurship in Bulgaria. // Knowledge - International Journal, September 2018, Institute of Knowledge Management, Skopje, Macedonia, 26, 2018, N1, pp.57-74, ISSN 1857-923X (for e-version), ISSN 2545 - 4439 (for printed version).

Terziev, V., Georgiev, M. (2018c). Characteristics of the Social Assistance System. // Sbornik dokladi ot godishna universitetska nauchna konferentsiya 14-15 yuni 2018 g., Elektronno izdanie, NVU Vasil Levski- Veliko Tarnovo, Veliko Tarnovo, 2018, str. 959-969, ISBN 978-619-7246-20-9 (online e-book), ISSN 2367-7481 (Терзиев, В., Георгиев, М. Характеристики на системата за социално подпомагане. // Сборник доклади от годишна университетска научна конференция 14-15 юни 2018 г., Електронно издание, НВУ Васил Левски- Велико Търново, Велико Търново, 2018, стр. 959-969, ISBN 978-619-7246-20-9 (online e-book), ISSN 2367-7481).

Terziev, V., Georgiev, M. (2018d). Social Protection of Vulnerable Populations in Bulgaria. // Sbornik dokladi 
ot godishna universitetska nauchna konferentsiya 14-15 yuni 2018 g., Elektronno izdanie, NVU Vasil Levski- Veliko Tarnovo, Veliko Tarnovo, 2018, str. 970-975, ISBN 978-619-7246-20-9 (online e-book), ISSN 2367-7481 (Терзиев, В., Георгиев, М. Социална защита на уязвимите групи от населението в България. // Сборник доклади от годишна университетска научна конференция 14-15 юни 2018 г., Електронно издание, НВУ Васил Левски- Велико Търново, Велико Търново, 2018, стр. 970-975, ISBN 978-619-7246-20-9 (online e-book), ISSN 2367-7481).

Terziev, V., Banabakova, V., Georgiev, M. (2018e). Modern dimensions of social policies. // International journal scientific papers Vol 23.4 Promoted in Budva, Montenegro 24-27.05.2018, IKM - Skopje, 23, 2018, N 4, pp. 935-944, ISSN 1857-923X (for e-version) ISSN 2545- 4439 (for printed version).

Terziev, V., Banabakova, V., Georgiev, M. (2018f). Social support as part of social policy. // International journal scientific papers Vol 23.4 Promoted in Budva, Montenegro 24-27.05.2018, IKM - Skopje, 23, 2018, N 4, pp. 973-980, ISSN 1857-923X (for e-version) ISSN 2545 - 4439 (for printed version).

Terziev, V., Banabakova, V., Georgiev, M. (2018g). Structure of the social welfare system in Bulgaria. // International journal scientific papers Vol 23.4 Promoted in Budva, Montenegro 24-27.05.2018, IKM Skopje, 23, 2018, N 4, pp. 1275-1281, ISSN 1857-923X (for e-version) ISSN 2545 - 4439 (for printed version).

Terziev, V., Banabakova, V., Georgiev, M. (2018h). Role and place of social programing in public governance. // Mizhnarodnoï naukovo-praktichnoï konferentsiï «Zabezpechennya stalogo rozvitku ekonomiki: problemi, mozhlivosti, perspektivi» (16-17 lyutogo 2018 roku, m. Uzhgorod), Ministerstvo osviti i nauki Ukraïni Uzhgorodsykiy natsionalyniy universitet, 2018, s.93-98, ISBN 978-966-916-488-9 (Terziev, V., Banabakova, V., Georgiev, M. Role and place of social programing in public governance. // Міжнародної науково-практичної конференції «Забезпечення сталого розвитку економіки: проблеми, можливості, перспективи» (16-17 лютого 2018 року, м. Ужгород), Міністерство освіти і науки України Ужгородський національний університет, 2018, с.93-98, ISBN 978-966-916-488-9).

Terziev, V., Banabakova, V., Georgiev, M. (2018i). Social program as a product of social programming. // Mizhnarodnoï naukovo-praktichnoï konferentsiï «Zabezpechennya stalogo rozvitku ekonomiki: problemi, mozhlivosti, perspektivi» (16-17 lyutogo 2018 roku, m. Uzhgorod), Ministerstvo osviti i nauki Ukraïni Uzhgorodsykiy natsionalyniy universitet, 2018, s. 99-104, ISBN 978-966-916-488-9 (Terziev, V., Banabakova, V., Georgiev, M. Social program as a product of social programming. // Міжнародної науково-практичної конфреренції «Забезпечення сталого розвитку економіки: проблеми, можливості, перспективи» (16-17 лютого 2018 року, м. Ужгород), Міністерство освіти і науки України Ужгородський національний університет, 2018, с. 99-104, ISBN 978-966-916-488-9).

Terziev, V., Banabakova, V., Georgiev, M. (2018j). Social efficiency as a measure of social activities. // Mizhnarodnoï naukovo-praktichnoï konferentsiï «Zabezpechennya stalogo rozvitku ekonomiki: problemi, mozhlivosti, perspektivi» (16-17 lyutogo 2018 roku, m. Uzhgorod), Ministerstvo osviti i nauki Ukraïni Uzhgorodsykiy natsionalyniy universitet, 2018, s. 104-109, ISBN 978-966-916-488-9 (Terziev, V., Banabakova, V., Georgiev, M. Assessment of the effectiveness of social programing. // Міжнародної науково-практичної конфреренції «Забезпечення сталого розвитку економіки: проблеми, можливості, перспективи» (16-17 лютого 2018 року, м. Ужгород), Міністерство освіти і науки України Ужгородський національний університет, 2018, с. 110-115, ISBN 978-966-916-4889).

Terziev, V., Banabakova, V., Georgiev, M. (2018k). Social activity of human resource as a basis of effective social policy. // Mizhnarodnoï naukovo-praktichnoï konferentsiï «Zabezpechennya stalogo rozvitku ekonomiki: problemi, mozhlivosti, perspektivi» (16-17 lyutogo 2018 roku, m. Uzhgorod), Ministerstvo osviti i nauki Ukraïni Uzhgorodsykiy natsionalyniy universitet, 2018, s. 116-121, ISBN 978-966-916488-9 (Terziev, V., Banabakova, V., Georgiev, M. Social activity of human resource as a basis of effective social policy. // Міжнародної науково-практичної конфреренції «Забезпечення сталого розвитку економіки: проблеми, можливості, перспективи» (16-17 лютого 2018 року, м. Ужгород), Міністерство освіти і науки України Ужгородський національний університет, 2018, с. 116-121, ISBN 978-966-916-488-9).

Terziev, V., Banabakova, V., Georgiev, M. (2018I). Strategic advantages of an active social program. // Міжнародної науково-практичної конференції «Забезпечення сталого розвитку економіки: проблеми, можливості, перспективи» (16-17 лютого 2018 року, м. Ужгород), Міністерство освіти і науки України Ужгородський національний університет, 2018, с. 122-127, ISBN 978-966-916-4889 (Terziev, V., Banabakova, V., Georgiev, M. Strategic advantages of an active social program. // Міжнародної науково-практичної конференції «Забезпечення сталого розвитку економіки: 
проблеми, можливості, перспективи» (16-17 лютого 2018 року, м. Ужгород), Міністерство освіти і науки України Ужгородський національний університет, 2018, с. 122-127, ISBN 978-966-916-4889).

Terziev, V., Banabakova, V., Georgiev, M. (2018m). Assessment of the effectiveness of social programming. // Mizhnarodnoï naukovo-praktichnoï konferentsiï «Zabezpechennya stalogo rozvitku ekonomiki: problemi, mozhlivosti, perspektivi» (16-17 lyutogo 2018 roku, m. Uzhgorod), Ministerstvo osviti i nauki Ukraïni Uzhgorodsykiy natsionalyniy universitet, 2018, s. 127-131, ISBN 978-966-916-488-9 (Terziev, V., Banabakova, V., Georgiev, M. Assessment of the effectiveness of social programming. // Міжнародної науково-практичної конференції «Забезпечення сталого розвитку економіки: проблеми, можливості, перспективи» (16-17 лютого 2018 року, м. Ужгород), Міністерство освіти і науки України Ужгородський національний університет, 2018, с. 127-131, ISBN 978-966-916-4889).

Terziev, V., Banabakova, V., Georgiev, M. (2018n). The social program as a part of development strategies. // Mizhnarodnoï naukovo-praktichnoï konferentsiï «Zabezpechennya stalogo rozvitku ekonomiki: problemi, mozhlivosti, perspektivi» (16-17 lyutogo 2018 roku, m. Uzhgorod), Ministerstvo osviti i nauki Ukraïni Uzhgorodsykiy natsionalyniy universitet, 2018, s. 132-137, ISBN 978-966-916-488-9 (Terziev, V., Banabakova, V., Georgiev, M. The social program as a part of development strategies. // Міжнародної науково-практичної конференції «Забезпечення сталого розвитку економіки: проблеми, можливості, перспективи» (16-17 лютого 2018 року, м. Ужгород), Міністерство освіти і науки України Ужгородський національний університет, 2018, с. 132-137, ISBN 978-966-916-4889).

Terziev, V., Banabakova, V., Georgiev, M. (20180). Social programming as a possibility to increase social efficiency. // Mizhnarodnoï naukovo-praktichnoï konferentsiï «Zabezpechennya stalogo rozvitku ekonomiki: problemi, mozhlivosti, perspektivi» (16-17 lyutogo 2018 roku, m. Uzhgorod), Ministerstvo osviti i nauki Ukraïni Uzhgorodsykiy natsionalyniy universitet, 2018, s. 137-142, ISBN 978-966-916488-9 (Terziev, V., Banabakova, V., Georgiev, M. Social programming as a possibility to increase social efficiency. // Міжнародної науково-практичної конференції «Забезпечення сталого розвитку економіки: проблеми, можливості, перспективи» (16-17 лютого 2018 року, м. Ужгород), Міністерство освіти і науки України Ужгородський національний університет, 2018, с. 137-142, ISBN 978-966-916-488-9).

Dimitrova, P., Georgiev, M. (2017a). Model of methodology for determining the needs of continuing vocationaltraining work specialists providing social services. // Innovatsii, tehnologii, nauka. Sbornik statey Mezhdunarodnoy nauchno - prakticheskoy konferentsii 25 yanvarya 2017 g., NITS Aeterna Permy, Chasty 4, 2017, s. 204-235, ISBN 978-5-906925-99-2, ISBN 978-5-00109-000-7 (Dimitrova, P., Georgiev M. Model of methodology for determining the needs of continuing vocationaltraining work specialists providing social services. // Инновации, технологии, наука. Сборник статей Международной научно - практической конференции 25 января 2017 г., НИЦ Аэтерна Пермь, Часть 4, 2017, с. 204-235, ISBN 978-5-906925-99-2, ISBN 978-5-00109-000-7).

Dimitrova, P., Georgiev, M. (2017b). Research, identification and monitoring of the needs of occupational training of social activities experts. // Innovatsii, tehnologii, nauka. Sbornik statey Mezhdunarodnoy nauchno - prakticheskoy konferentsii 25 yanvarya 2017 g., NITS Aeterna Permy, Chasty 4, 2017, s. 235-258, ISBN 978-5-906925-99-2, ISBN 978-5-00109-000-7 (Dimitrova, P., Georgiev M. Research, identification and monitoring of the needs of occupational training of social activities experts. // Инновации, технологии, наука. Сборник статей Международной научно - практической конференции 25 января 2017 г., НИЦ Аэтерна Пермь, Часть 4, 2017, с. 235-258, ISBN 978-5906925-99-2, ISBN 978-5-00109-000-7).

Terziev, V., Banabakova, V., Arabska, E. (2018p). The experience of the centres for provision of integrated employment and social assistance services in Bulgaria. // Upravlenie i Obrazovanie, Universitet "Prof. d-r Asen Zlatarov", Burgas, 14, 2018, N 1, str.5-14, ISSN 13126121. (Terziev, V., Banabakova, V., Arabska, E. The experience of the centres for provision of integrated employment and social assistance services in Bulgaria. // Управление и Образование, Университет "Проф. д-р Асен Златаров", Бургас, 14, 2018, N 1, стр.5-14, ISSN 13126121).

Terziev, V., Arabska, E., Banabakova, V., Kovalyov, E. (2018q). Bolgarsko-Rossiyskoe sotrudnichestvo v oblasti proektirovaniya i realizatsii mezhdunarodnayh setevayh obrazovatelynayh programm. // Sozdanie komfortnoy sreday sotsializatsii uchashtihsya, studentov i uchyonayh, Akademiya za inovatsii i ustoychivost - Plovdiv, Balgariya, 2018, str. 65-69, ISBN 978-619-7246-17-9 (print) ISBN 
978-619-7246-18-6 (DVD). Терзиев, В., Арабска, Е., Банабакова, В. Ковалёв, Э. БолгарскоРоссийское сотрудничество в области проектирования и реализации международных сетевых образовательных программ. // Создание комфортной среды социализации учащихся, студентов и учёных, Академия за иновации и устойчивост - Пловдив, България, 2018, стр. 65-69, ISBN 978-619-7246-17-9 (print) ISBN 978-619-7246-18-6 (DVD).

Terziev, V., Arabska, E., Banabakova, V., Ignatova, M., Kovalyov, E. (2018r). Vliyanie tvorchestva G. V. Sviridova na kachestvo sotsializatsii studencheskoy molodyozhi. // Sozdanie komfortnoy sreday sotsializatsii uchashtihsya, studentov i uchyonayh, Akademiya za inovatsii i ustoychivost - Plovdiv, Balgariya, 2018, str. 71-80, ISBN 978-619-7246-17-9 (print) ISBN 978-619-7246-18-6 (DVD). Терзиев, В., Арабска, Е., Банабакова, В., Игнатова, М., Ковалёв, Э. Влияние творчества Г. В. Свиридова на качество социализации студенческой молодёжи. // Создание комфортной среды социализации учащихся, студентов и учёных, Академия за иновации и устойчивост - Пловдив, България, 2018, стр. 71-80, ISBN 978-619-7246-17-9 (print) ISBN 978-619-7246-18-6 (DVD).

Terziev, V., Arabska, E., Banabakova, V. (2018s). Sotsialyno-ekonomicheskoe polozhenie nezashtishtyonnayh sloyov naseleniya. // Sozdanie komfortnoy sreday sotsializatsii uchashtihsya, studentov i uchyonayh, Akademiya za inovatsii i ustoychivost - Plovdiv, Balgariya, 2018, str. 87-89, ISBN 978-619-7246-17-9 (print) ISBN 978-619-7246-18-6 (DVD). Терзиев, В., Арабска, E., Банабакова, В. Социально-экономическое положение незащищённых слоёв населения. // Создание комфортной среды социализации учащихся, студентов и учёных, Академия за иновации и устойчивост - Пловдив, България, 2018, стр. 87-89, ISBN 978-619-7246-17-9 (print) ISBN 978-619-7246-18-6 (DVD).

Terziev, Venelin. (2016a). Process of deinstitutionalization of children at risk in Bulgaria. // Fifth Annual International Research-to-Practice Conference «Early Childhood Care and Education» (ECCE 2016). 12-14 May, 2016, Lomonosov Moscow State University - MSU, Moscow, Russia, 2016, ISSN 23086408, pp.170-179.

Terziev, Venelin. (2017c). Prevention and support to persons at risk of social marginalization. // Children \& Schools, 39, 2017, N 4(2), pp. 1139- 1150, ISSN 1532-8759, Source Normalized Impact per Paper (SNIP): 0.400 SCImago Journal Rank (SJR): 0.211 Impact factor: 1.086 5-Yr impact factor: 1.152.

Terziev, V., Radev, D., Arabska, E., Dimitrovski, R. (2017d). Deinstitutionalisation of children as part of the development of social services in Bulgaria. // Twelfth international scientific conference Knowledge without borders, 31.3-2.4.2017, Vrnjacka Banja, Serbia, Institute of Knowledge Management, Skopje 16, 2017, N 1, ISSN 1857-923X, pp.19-28.

Terziev, Venelin. (2017e). The system of social services in Bulgaria and the process of deinstitutionalisation of children. // Proceedings of the VII International Academic Congress "Fundamental and Applied Studies in EU and CIS Countries" (United Kingdom, Cambridge, England, 26-28 February 2017). Cambridge University Press, 7, 2017, ISBN: 978-0-875-83597-4, pp.338-351, Source Normalized Impact per Paper (SNIP): 5.192 SCImago Journal Rank (SJR): 5.186 Impact factor: 7.549. 